\title{
Is the Low Electoral Turnout of Indigenous People a Myth? Evidence from Subnational Elections in Chile, 2012-2017
}

\author{
Mauricio Morales Quiroga ${ }^{1}$ \\ University of Talca, Santiago-Chile
}

\begin{abstract}
Abundant evidence exists of the low electoral turnout of indigenous people. Among the reasons that explain this result are the weakness of political parties in representing indigenous people, the economic circumstances of ethnic minorities, and their experiences of discrimination. In general, these findings are based on analyses of national elections, and it is unclear if they hold equally at the subnational level. This study of the Mapuche ethnic group in Chile analyzed the electoral turnout in Chile's 345 municipalities for the national elections of 2013 and 2017 and the subnational elections of 2012 and 2016. The study found the following. First, the electoral turnout in municipalities with the highest concentration of Mapuche is above the average for subnational elections and comparable to the average for national elections. Second, the electoral turnout in these municipalities increases in those subnational elections in which candidates with Mapuche surnames compete. Third, the electoral turnout increases even more in those municipalities in which Mapuche mayoral candidates win in subnational elections.
\end{abstract}

Keywords: Chile, electoral turnout, Mapuche, representation, subnational elections.

In general, the literature on ethnic voting in Latin America has focused on explaining the emergence of ethnic political parties (Rice \& Van Cott, 2006; Van Cott, 2005), the role of indigenous movements in the political systems of the region (Yashar, 2005), the rise of ethnopopulism (Madrid, 2018), and the political representation obtained by indigenous minorities according to different institutional designs (Htun, 2016; Lublin, 2017a; Madrid, 2012). As far as the electoral turnout of indigenous people is concerned and following Martínez i Coma and Nai (2017), comparative studies tend to consider ethnic diversity as a control variable rather than a central variable in explaining electoral turnout. In doing so, they prefer to analyze the political representation of indigenous people rather than their electoral turnout. In Latin America, however, some case studies do relate electoral turnout to indigenous populations, and they find the relationship to be an inverse one; indigenous people vote less than the rest of the population. Studies on Guatemala (Lehoucp \& Wall, 2004), Mexico (Hiskey \& Goodman, 2011), and Chile (Fuentes et al., 2019) are examples.

Four reasons are given to explain this result. First, the absence of parties, whether ethnic or non-ethnic, capable of representing the interests of the indigenous population (Madrid, 2005). Second, experiences of social discrimination suffered by indigenous people and minorities in general that produce a kind of self-marginalization from the public space (Oskooii, 2018). Third, the increasing tendency of political parties to practice selective vote-buying based on people's skin

\footnotetext{
${ }^{1}$ Correspondent Author E-mail: mmoralesq@utalca.cl
} 
color, a form of electoral discrimination with the long-term result that only those who receive some benefit from voting participate (Johnson, 2020). Fourth, reduced perceptions of ethnic minorities of electoral fairness lessens their interest in voting (Flesken \& Hartl, 2020).

These reasons are useful for explaining indigenous people's electoral turnout in national elections for president and the legislature. Given that in these elections, the candidates seek the support of the average voter and large groups of the population, it is not surprising that indigenous people feel little enthusiasm for the election of these national authorities. Candidates will hardly consider the social and economic problems of indigenous people as a central issue in their programs unless, in that election, an indigenous cleavage has emerged that structures a new party system (Dunning \& Harrison 2010; Felson, 1984; Knoke \& Madrid, 2005). In its absence, indigenous people can be expected to have lower levels of electoral turnout than the rest of the population. However, will this also be true at the subnational level? Rosenthal et al.'s (2017) study shows that the participation of Muslim Arabs in Israel is higher in subnational elections than in national elections. Presumably, the authors argue, this response is related to a simple fact: ethnic minorities vote in greater number when they elect authorities closer to them and more likely to represent them substantively by promoting their access to public goods. This argument also aligned with Geys's (2006) point in his study on the determinants of electoral participation. Geys emphasizes that electoral turnout will be greater in small geographic areas and in elections in which the representatives to be chosen are closer to the voter.

This article suggests some further arguments that complement this approach. Indigenous people vote more in subnational elections than in national elections, especially when they are concentrated in specific territories in which demands on the political system are much more concrete. However, when an indigenous people is dispersed over the country and consequently has lower levels of organization, this may not be the case. In subnational elections - unlike national elections - indigenous people are electorally decisive. Despite being a minority at the national level, they become a majority when concentrated in a territory where they elect their own authorities. If a territory elects a mayor to govern a municipality and $80 \%$ of that municipality's population is indigenous, the mayoral candidates must base their electoral platform on indigenous demands. In such elections, indigenous people have a capacity to influence the political results that they lack in national elections.

In addition, another factor driving electoral turnout in geographic areas with a higher concentration of indigenous people is the presence of candidates of the same ethnicity as that of the voters. Shared ethnicity involves greater proximity and resonance between representative and represented, thus strengthening what we understand by descriptive representation (Pitkin, 1967). This descriptive representation supposes - in the case of ethnic minorities - a kind of "informational shortcut" for voters. Given the distrust felt by these minorities for their national authorities, the presence at the local level of candidates with whom they share, for example, experiences of discrimination, poverty, and inequality, generates a bond of mutual understanding between voters and their potential representatives (Mansbridge, 1999). For voters, moreover, a representative of the same ethnic group is more likely to promote the preferences and interests of that minority, transforming a descriptive representation into a substantive one (Barreto et al., 2005; Carlson, 1984).

This study tested this argument by analyzing national and subnational elections in Chile, and specifically the electoral turnout of the Mapuche ethnic group, which represents close to 10\% of the population and is the largest ethnic minority in the country. The unit of analysis was Chile's 345 municipalities. The electoral turnout data and the percentage of Mapuches in each municipality were aggregated. At the same time, candidates belonging to the Mapuche ethnic group specifically mayoral and municipal council candidates for the subnational elections of 2012 and 2016 were 
classified by their surnames. Subsequently, the effect of the presence of Mapuche candidates on electoral participation at the municipal level was measured, controlling for other variables such as the percentage of poor residents and population density.

The article is divided into four sections. First, the theories about electoral participation and indigenous people and the hypotheses guiding this study are discussed. The second section discusses the research design. The third section presents the data analysis and the main findings. The fourth section includes a discussion and conclusions.

\section{Theory and Hypotheses}

Institutional variables associated with the electoral regime, such as whether the vote is compulsory or voluntary (Jackman, 1987; Mackerras \& McAllister, 1999; Powell, 1986); sociodemographic variables such as education (Almond \& Verba, 1963; Gallego, 2010; Lijphart,1997); income inequality (Stockemer \& Scruggs, 2012); variations in community size (Remmer, 2010) and rurality (Hofferth \& Iceland, 1998); and contingent factors on election day, such as the weather conditions (Gatrell \& Bierly, 2002; Persson et al., 2014), and the effect of standing in line to vote on the probability of voting in the next election (Pettigrew 2020) impact electoral turnout. Some studies have even measures the effect of people's genetic makeup on their probability of voting (Fowler \& Dawes, 2008).

In the case of electoral turnout and ethnic minority representation, additional considerations may apply. They include which electoral systems contribute most to a better representation of these minorities (Lublin, 2017b; Ordeshook \& Shvetsova, 1994); the capacity of parties or ethnic movements for mobilizing electors (Ambrecht \& Pachon, 1974; Arthur, 2009; Basedau \& Stroh, 2012; Chandra, 2004, 2005; Hahn \& Almy, 1971; Van Cott, 2005); and the presence of ethnic candidates who care able to strengthen the descriptive representation of these minorities (Dabin et al., 2018; Fisher et al., 2015). In the latter case, ethnic affinity voting (Bird et al., 2016; Dancygier, 2017; Featherman, 1983; Kamin, 1958; Manzano \& Sánchez, 2010; McConnaughy et al., 2011; Piliavin, 1987; Van der Zwan et al., 2020; Wolfinger, 1965), also known as ethnic solidarity voting (Contreras \& Morales, 2017; Toro \& Jaramillo, 2014), may be present.

In general, the electoral turnout of indigenous minorities tends to be lower compared to the rest of the population (Campbell, 2006; Förster, 2018; Martinez i Comma \& Nai, 2017) and that, even with a compulsory vote, ethnic fragmentation stimulates invalid voting, generating problems for the legitimacy of the electoral results (Martinez i Coma \& Werner, 2019). From another perspective, the argument has been made that, at least in the United States, racial differences in the electoral turnout are largely attributable to local election officials providing more poll workers and voting machines to more heavily white precincts, at the expense of precincts serving minority voters (Pettigrew, 2020).

In their study on Israel, Rosenthal et al. (2017) argued that the electoral turnout of ethnic minorities should be analyzed not only in national elections but also in subnational elections. They found that electoral turnout was higher in subnational elections. In these elections, such minorities, primarily when concentrated in specific territories, have greater decision-making power than in national elections. In national elections, the situation is different. Candidates attempt to represent majorities so that it is more difficult for ethnic minorities to gain their attention. Furthermore, in local elections, ethnic minorities aspire to achieve substantive representation by the authorities elected for their respective territories, a goal impossible for them to achieve in national elections (Rosenthal et al., 2017). 
This discussion indicates the importance of distinguishing between the electoral turnout of indigenous people at two levels: national and subnational elections. The following hypotheses are posited:

H1: In subnational elections, the higher the percentage of indigenous people, the higher the electoral turnout.

H2: In national elections, the higher the percentage of indigenous people, the lower the electoral turnout

Although the electoral turnout of indigenous people may differ when national and subnational elections are compared, what accounts for this difference is unclear. This paper suggests that electoral turnout also responds to the characteristics of the political offering. In alignment with the literature on ethnic affinity voting, the expectation of this paper is electoral turnout to increase when there are candidates who belong to the same ethnic minority as voters. Moreover, turnout increases even more when what Bobo and Gilliam (1990) call empowerment occurs. Empowerment is the ability of minorities to achieve political representation by choosing candidates who - in practice - could develop substantive representation (Barreto et al., 2005). Fraga (2016) has discussed this empowerment theory with data from elections in the United States. In the case of Latin America, meanwhile, some studies have shown the existence of an ethnic solidarity vote rather than analyzing electoral turnout, (Contreras \& Morales, 2017), the rise of ethnopopulism as a strategy for the electoral mobilization of ethnic minorities by populist candidates (Madrid, 2018), the creation of ethnic-based "niche parties" (Kernecker \& Wagner, 2019), and the emergence of indigenous political movements (Korovkin, 2006). Other studies concern themselves with the political inclinations of indigenous people in countries such as Ecuador (Akran, 2018; Beck \& Mijeski, 2006; James, 2018) and Brazil (Bueno \& Dunning, 2017).

All these studies, in one way or another, are based on ethnic affinity voting. Their main objective is to understand and explain ethnic representation rather than electoral turnout. The salient point is that the election of a candidate from an ethnic minority based on an ethnic affinity vote does not necessarily imply that that candidate has generated enough enthusiasm to motivate indigenous people to go out and vote. This does not ignore the possibility that such candidates may build something like an ethno-populist following (Madrid, 2011) due to their political characteristics and the personalistic style that they generally cultivate, Peru being a typical case.

Although there are works on the emergence and performance of ethnic parties at the subnational level (Rice \& Van Cott, 2006). this study relies on empowerment theory), in the absence of studies specifically on the electoral turnout in subnational elections in Latin America. Based on this theory, two hypotheses are posited:

\section{H3: The presence of candidates with a Mapuche surname for councillor increases the electoral} turnout of indigenous people.

H4: The presence of mayoral candidates with a Mapuche surname increases the electoral turnout of indigenous people.

In Chile, municipal governments consist of a mayor, elected in a relative majority electoral system, and a municipal council. The council consists of 6,8 , or 10 councilors, depending on the size of the municipality, elected in an open-list proportional system. One main function of the 
councillors is to oversee the work of the mayor and approve the development plan for each municipality.

\section{Why Chile?}

In comparative literature, Chile is considered to have one of Latin America's most stable party systems (Mainwaring \& Scully, 1995; Payne et al., 2003). At least until the 2013 presidential elections, two broad political coalitions, one of the center-left and the other of the center-right, monopolized electoral competition. In 2015, Chile moved from a binomial proportional electoral system - in which two candidates were elected as deputies (members of the Chamber of Deputies) every district - to a "more" proportional system in which between three and eight seats were distributed per district (Gamboa \& Morales, 2016). This system opened the way to an increase in fragmentation and the political alternatives on offer, in what amounted to a transformation of the party system. For example,14 parties competed in 2013, but 26 did so in 2017 . The effective number of parties increased from 8.7 in 2013 to 10.6 in 2017.

Notwithstanding this opening for greater political competition due to the change in the electoral system, in Chile, no ethnic parties have taken root, despite some failed attempts (Tricot \& Bidegain, 2020). In general, it is the traditional parties that include Mapuche candidates on their lists. Although there is an ethnic solidarity vote (Contreras \& Morales, 2017), the historical demands of the Mapuche people still await a response from the state. In fact, the Chilean Constitution does not recognize the existence of indigenous peoples, and they continue to experience poverty and exclusion (Valenzuela et al., 2017). This probably explains the lower electoral turnout of indigenous people in national elections. Given that the Chilean state has not addressed their demands for constitutional recognition and the return of their ancestral lands, it is hardly surprising that they opt out of these electoral processes.

Therefore, the links that indigenous people have with the political system rests fundamentally with the municipalities in which they live. Durston (2007) and Gundermann (2007) showed that, in general, indigenous people channel their demands through the local power system and the mediation of political leaders from their territories. These leaders mainly generate a client relationship with them, one that becomes more evident on election day. For this reason, Chile is an interesting case for analyzing the electoral turnout of indigenous people. For one thing, traditional political parties continue to coexist with emerging parties but without an ethnic party, a context in which indigenous political leaders must seek representation through the traditional parties. For another, indigenous people experience greater poverty and exclusion than the rest of the population. Their only space for connection with the political system is what the municipalities and the political leaders who govern them have to offer to satisfy their most immediate demands. The historic demands they have made to the Chilean state remain without resolution.

\section{Research Design}

This study analysed electoral turnout in Chile for the subnational elections of 2012 and 2016 and the national (presidential and parliamentary) elections of 2013 and 2017. The unit of analysis was the municipality, of which there are 345 in Chile. For each municipality, the percentage of electoral turnout and the percentage of the Mapuche population according to the 2012 and 2017 censuses was calculated. The study classified the candidates by their surnames. These were coded as " 1 " candidates who had at least one Mapuche surname and as " 0 " for the rest of the candidates. The Mapuche surnames were taken from an official document of the National 
Indigenous Development Corporation, CONADI (Painemal, 2011), and the Mapuche Data Project (http://mapuchedataproject.cl). This measurement is not perfect. There may be candidates who represent Mapuche voters but who do not have a Mapuche surname. Equally, there may be candidates with a Mapuche surname whose aim is not necessarily to represent Mapuche voters. Because both situations are unusual, particularly in municipalities with a high concentration of Mapuche population, this situation is a potential limitation of this study.

After classifying the candidates by their surnames, their percentage of votes were calculated and divided into winners and losers (specifically, in the case of mayors). In total, 25,423 candidates for mayor and councillor for the local elections of 2012 and 2016 were calculated. The percentage of Mapuche candidates is low at the national level, although highly concentrated in some regions of the country, specifically in regions and municipalities with the highest percentage of the Mapuche population.

Finally, two control variables were calculated: the percentage of poor people and population density. Both are generally used in the comparative literature on electoral turnout (Anderson \& Beramendi, 2008; Blais, 2006; Blais et al., 2004; Dalton, 2017; Lijphart, 1997; Stockemer \& Scruggs, 2012), and in Chile (Contreras et al., 2016; Corvalán \& Cox, 2013). This study did not use opinion polls for two reasons. First was because generally, the Mapuche population appears to be underrepresented in them. For example, according to the surveys of the Center for Public Studies (CEP) in 2016 and 2017, the Mapuche population stood at $6.3 \%$ and $8.1 \%$, respectively, whereas the official figure, according to the census, was $9.9 \%$. Second, because without opinion polls, it is impossible to link the electoral behavior of the Mapuches with the characteristics of the political offer for each individual. The surveys available are of national representation and not of municipal representation.

\section{Data Analysis and Findings}

Table 1 shows the variables used to analyze the data with all their descriptive statistics. The dependent variable was the electoral turnout for the subnational elections of 2012 and 2016 and the national elections of 2013 and 2017. Two control variables, poverty and population density for all the years, were analyzed. These variables are useful to avoid possible spurious relationships between the dependent variable and the two main independent variables - the percentage of Mapuches by the municipality and the political offer of Mapuche candidates.

The table also gives descriptive statistics for the Mapuche percentage of the population. These percentages are not homogeneous throughout the country but are concentrated in some municipalities and regions. Finally, the table provides descriptive statistics of the political offer of Mapuche candidates for mayor and councilors in all the municipalities of the country. For example, in 2016, 66 Mapuche candidates competed in the mayoral election of a total of 1,211 candidates $(5.45 \%)$. In the case of mayors, who are the most important local figure in the municipality, the percentage of Mapuche mayors elected was used. Seventeen Mapuche mayors were elected in 2012 (4.9\%); 19 were elected in $2016(5.5 \%)$.

Figure 1 shows the electoral turnout by region for the 2016 subnational elections and the 2017 national elections. In the 2016 subnational elections, the biggest outlier was the Metropolitan Region, in which participation was 5 points below the country average. Meanwhile, in the southern regions of Chile-where a large percentage of the Mapuche population is concentrated - the electoral turnout was very close to the average. In the 2017 national election, no great regional differences were present in electoral turnout, except for the extreme northern and southern regions that historically have shown lower levels of turnout. 


\section{Table 1}

Descriptive Statistics

\begin{tabular}{lccccc}
\hline Variable & Obs & Mean & Std.Dev. & Min & Max \\
\hline Turnout 2012 & 345 & 43.2 & 10.79 & 26.78 & 79.99 \\
Turnout 2016 & 345 & 34.89 & 12.27 & 21.16 & 75.75 \\
Turnout 2013 & 345 & 49.35 & 7.88 & 15.14 & 67.66 \\
Turnout 2017 & 345 & 46.69 & 7.06 & 13.07 & 69.08 \\
Mapuches (\%) & 345 & 9.90 & 9.47 & 0.69 & 83.23 \\
Poverty (\%) & 345 & 21.04 & 10.94 & .29 & 59.74 \\
Density & 345 & 2836.04 & 4383.67 & 0.03 & 17435.1 \\
Mapuche mayoral candidates 2012 & 345 & 4.48 & 12.48 & 0 & 75 \\
$\quad(\%)$ & & & & & \\
Mapuche candidates for councilor & 345 & 5.45 & 15.27 & 0 & 100 \\
$\quad$ 2016 (\%) & 345 & 8.17 & 11.1 & 0 & 59.25 \\
Mapouches candidates for councilor & & & & & \\
$\quad$ 2012 (\%) & 345 & 7.71 & 10.85 & 0 & 62.96 \\
Mapuche candidates for councilor & & & & & \\
$\quad$ 2016 (\%) & 345 & 0.049 & 0.216 & 0 & 1 \\
Mapuche mayors 2012 & 345 & 0.055 & 0.228 & 0 & 1 \\
Mapuche mayors 2016 & & & & & \\
\hline
\end{tabular}

Note. Compilation of data from www.servel.cl, www.subdere.cl and www.ine.cl

Figure 1

Electoral Turnout by Region, 2016 and 2017

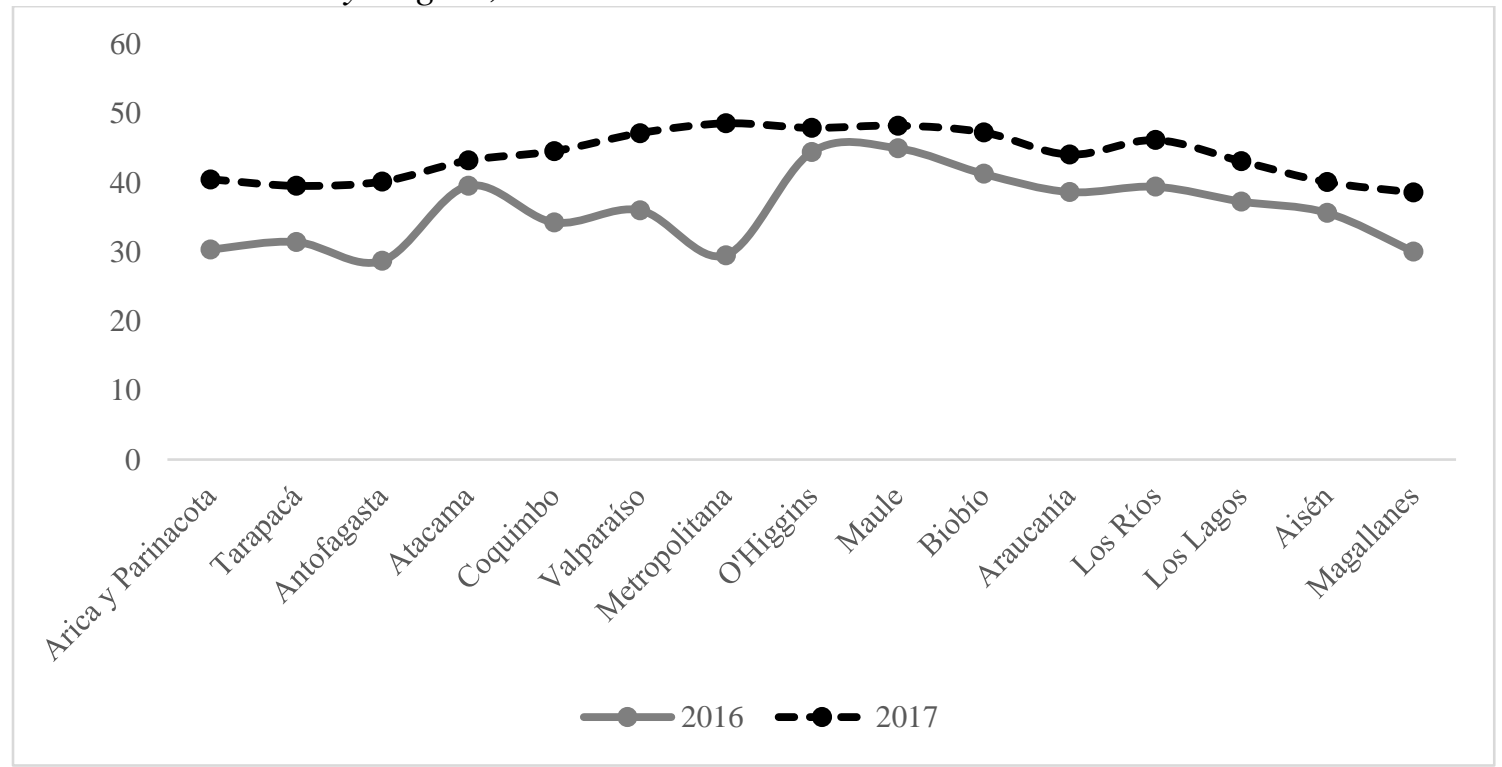

Note. Created with data from www.servel.cl

Figure 2 shows the percentage of the Mapuche population by region. As can be seen, the regions with the highest percentages of the Mapuche population are Araucanía (AR), Los Ríos (LR), Los Lagos (LL), and Aysén (AY). All four regions have a Mapuche population percentage greater than $20 \%$, although with wide variations between the municipalities into which each region 
is divided. In some municipalities within the same region, the Mapuche population is as high as $80 \%$, while in others, it does not reach $20 \%$.

This high municipal variance contributes to this research in the following way. Given that within the same region, there are municipalities with a high percentage of the Mapuche population and other municipalities with a low percentage, within the same region, municipalities with similar attributes in terms of poverty and density be compared with those that differ regarding their percentage of Mapuche population and supply of Mapuche candidates. In this way, it will be easier to identify precisely the effect of the concentration of the Mapuche population on the electoral turnout.

Figure 2

Percentage of Mapuche Population by Region, 2017 Census

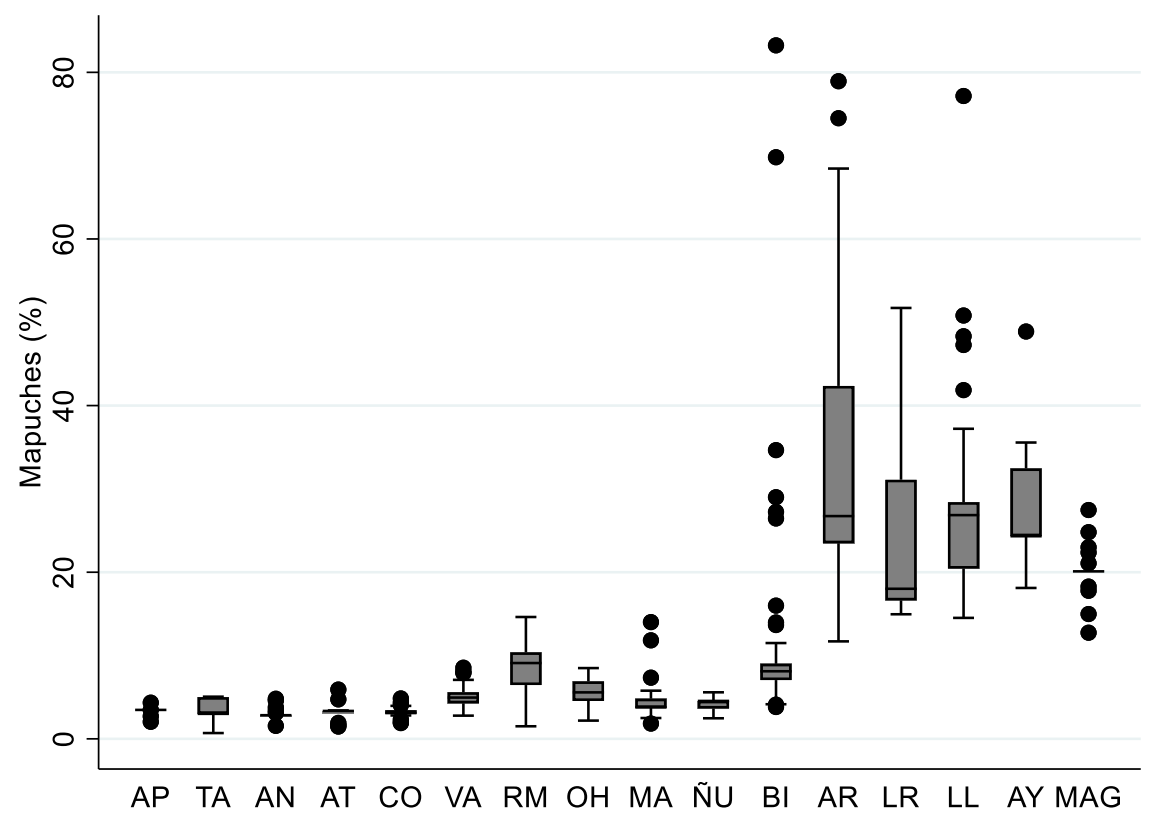

Note. Created with data from www.ine.cl

$\mathrm{AP}=$ Arica \& Parinacota; $\mathrm{TA}=$ Tarapacá; $\mathrm{AN}=$ Antofagasta; $\mathrm{AT}=$ Atacama; $\mathrm{CO}=$ Coquimbo; $\mathrm{VA}=$ Valparaíso; $\mathrm{RM}=$ Región Metropolitana; $\mathrm{OH}=$ O’Higgins; $\mathrm{MA}=$ Maule; $\mathrm{BI}=\mathrm{B}$ íoBío; $\mathrm{AR}=$ Araucanía; LR= Los Ríos; LL= Los Lagos; $\mathrm{AY}=$ Aysén; MAG= Magallanes.

To distinguish between those territories with the highest concentration of the Mapuche population and the rest of the country, the study divided the country into two groups. The first group consists of those regions (of a total of 15) with the highest percentage of the Mapuche population in proportion to their population sizes. According to the 2017 census, the Araucanía region takes first place with 32.8\%, followed by Aysén (26.8\%), Los Ríos (24.2\%), and Los Lagos (26.7\%) on this dimension. The second group consists of the municipalities belonging to the other regions of the country.

Table 3 shows the correlation coefficients between electoral turnout and the percentage of the municipality's Mapuche population for the local elections of 2012 and 2016 and the national elections of 2013 and 2017. As noted, in the group of municipalities belonging to the regions with the highest percentage of the Mapuche population, the correlation coefficients rise to 0.42 and 0.43 for the local elections of 2012 and 2016 and drop to $0.08-0.14$ for the national elections. In 
municipalities that belong to the remaining regions of the country, the correlation coefficients are always negative, with values lower than -0.2. Thus, in the case of local elections, increases in the percentage of the Mapuche population in the municipalities belonging to the regions with the highest percentage of the Mapuche population are associated with increases in electoral turnout. In contrast, in the rest of the country, increases in the percentage of the Mapuche population are associated with lower levels of electoral turnout. In the case of national elections, the correlation coefficients for the group of municipalities in regions with a higher percentage of the Mapuche population are close to 0 , while in the rest of the country, these coefficients have values of -0.17 for the elections of 2013 and -0.18 for the 2017 elections.

\section{Table 2}

Electoral Turnout in the Ten Municipalities with the Largest Mapuche Population, 2012 and 2016 Subnational Elections, 2013 and 2017 National Elections

\begin{tabular}{lcccccc}
\hline & Region & $\begin{array}{c}\text { Percentage } \\
\text { of Mapuche } \\
\text { population }\end{array}$ & $\begin{array}{c}\text { Subnational } \\
(2012)\end{array}$ & $\begin{array}{c}\text { National } \\
(2013)\end{array}$ & $\begin{array}{c}\text { Subnational } \\
(2016)\end{array}$ & $\begin{array}{c}\text { National } \\
(2017)\end{array}$ \\
\hline Alto BioBio & BioBio & 83.2 & 60.5 & 42.3 & 59.2 & 35.5 \\
Saavedra & Araucanía & 78.9 & 52.0 & 47.2 & 50.6 & 41.4 \\
San Juan de la Costa & Los Lagos & 77.2 & 55.4 & 54.8 & 49.5 & 48.6 \\
Chol Chol & Araucanía & 74.5 & 66.2 & 57.9 & 60.9 & 43.3 \\
Tirúa & BioBio & 69.8 & 66.0 & 50.5 & 61.8 & 45.7 \\
Galvarino & Araucanía & 68.4 & 56.5 & 52.2 & 54.8 & 45.1 \\
Curarrehue & Araucanía & 65.2 & 60.0 & 44.7 & 50.2 & 37.6 \\
Nueva Imperial & Araucanía & 55.4 & 54.6 & 52.9 & 45.9 & 46.7 \\
Lonquimay & Araucanía & 53.8 & 54.3 & 40.3 & 53.5 & 38.3 \\
Freire & Araucanía & 53.4 & 47.2 & 48.9 & 41.9 & 42.0 \\
\hline Average & & 64.0 & 55.4 & 49.8 & 50.4 & 43.5 \\
Total average & & 9.9 & 43.2 & 49.4 & 34.9 & 46.7 \\
\hline Note. Created & & & & & & \\
\hline
\end{tabular}

Note. Created with data from www.servel.cl and www.ine.cl

Figure 3 compares the correlations for the 2016 local elections and the 2017 national elections in the two groups analyzed, i.e., the municipalities grouped in regions with a higher percentage of the Mapuche population versus the rest of the country.

Table 3

Coefficients of Correlation Between Electoral Turnout and the Percentage of Mapuche Population 2012-2017

Araucanía, Los Ríos, Los
Lagos, Aysén

\begin{tabular}{lcc}
\hline Subnational Elections (2012) & 0.42 & -0.15 \\
National Elections (2013) & 0.08 & -0.17 \\
Subnational Elections (2016) & 0.43 & -0.18 \\
National Elections (2017) & -0.14 & -0.18 \\
\hline
\end{tabular}

Note. Compilation of data from www.servel.cl and www.ine.cl

To test the hypothesis, a set of weighted least square models (WLS) based on an ecological regression was used. The main reason for using a WLS instead of an ordinary least square (OLS) model was that in the case of Chile, municipalities have high variance in the population. There are some municipalities with more than 300,000 voters and others that barely have 2,000. Thus, by 
weighting the cases according to the electoral roll of each municipality, more precise inferences can be made (a $40 \%$ turnout in a municipality with only 2,000 voters is not the same as in a municipality with 300,000 voters. My basic statistical model is the following:

$$
\begin{aligned}
\text { ETURNOUT }_{i} & =B_{f} \text { GROUPS }+B_{1} \text { MAPPEOPLE }_{i}+B_{f} \text { GROUPS } * B_{1} \text { MAPPEOPLE } \\
& +e i
\end{aligned}
$$

Figure 3

The Relationship Between Electoral Turnout and the Percentage of Mapuches, 2016 Subnational Elections and 2017 National Elections

Local Elections (2016)

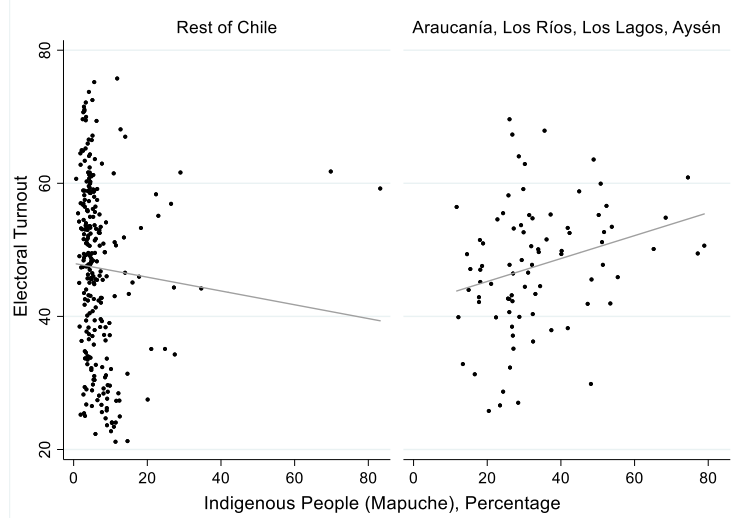

National Elections (2017)

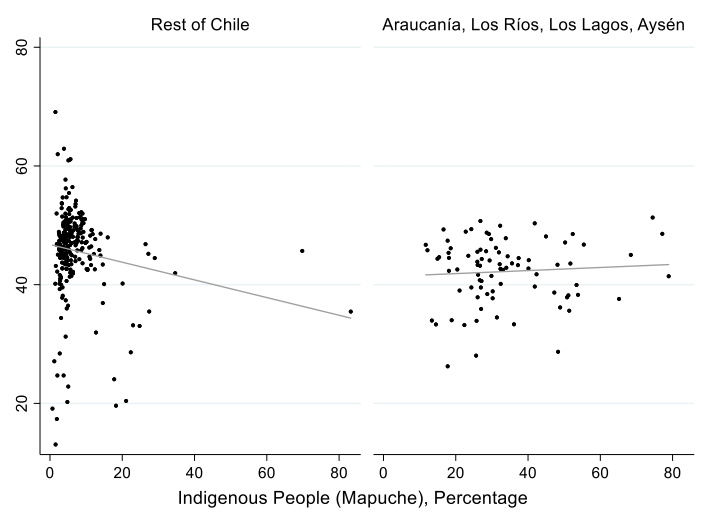

Note. Compilation of data from www.servel.cl and www.ine.cl

Where "i" is each municipality, ETURNOUT is the percentage of each municipality's electoral turnout; GROUPS is a dichotomous variable that has the value of 1 when the municipality belongs to the regions with the highest percentage of the Mapuche population (Araucanía, Los Ríos, Los Lagos, and Aysén), and which has the value of 0 when the municipality belongs to the rest of the country; MAPPEOPLE is the percentage of the Mapuche population per municipality.

The model includes an interaction term between GROUPS and MAPPEOPLE to distinguish the effect on the electoral turnout of the percentage of the Mapuche population in the regions with the highest percentage of the Mapuche population from that of the rest of the country. Finally, $\sum_{j=1}^{N} \delta_{j i}$ is the set of county dummies, with $\mathrm{N}=345$. The baseline estimation assumes that the error term ei is clustered by the county, which allows the statistical models to be specified as Ecological Regressions (Gelman et al., 2001)

Table 4 gives the results of these baseline models for the local elections of 2012 and 2016 and the national elections of 2013 and 2017.

These models show that the main findings are as follows. First, increases in the percentage of the Mapuche population predict a reverse in electoral turnout. Second, that (on average) the municipalities that belong to the regions with the highest percentage of the Mapuche population register a lower electoral turnout than the rest of the country. Third, in the group of municipalities that belong to the regions with the highest percentage of the Mapuche population, increases in the percentage of Mapuche population predict an increase in the electoral turnout, except for the 2017 national elections, in which the coefficient of the interaction term was not statistically significant. 
Table 4

Determinants of Electoral Turnout (WLS) Ecological Regression, 2012-2017

$2012 \quad 2013 \quad 2016 \quad 2017$

\begin{tabular}{lcccc} 
MAPPEOPLE & $-0.331^{*}$ & $-0.205^{*}$ & $-0.423^{* *}$ & $-0.222^{*}$ \\
& $(0.191)$ & $(0.106)$ & $(0.208)$ & $(0.114)$ \\
GROPUPS & $-7.891^{* *}$ & $-4.329 * *$ & $-9.545^{* *}$ & $-3.759 *$ \\
& $(3.710)$ & $(1.884)$ & $(4.201)$ & $(1.977)$ \\
GROUPS*MAPPEOPLE & $0.627 * * *$ & $0.235^{* *}$ & $0.776^{* * *}$ & 0.181 \\
& $(0.207)$ & $(0.114)$ & $(0.229)$ & $(0.122)$ \\
Constant & $45.12^{* * *}$ & $51.11^{* * *}$ & $37.37 * * *$ & $48.55^{* * *}$ \\
& $(1.547)$ & $(1.097)$ & $(1.631)$ & $(1.231)$ \\
Observations & & & & \\
R-squared & 345 & 345 & 345 & 345 \\
Log Lik & 0.056 & 0.044 & 0.069 & 0.074 \\
\hline
\end{tabular}

Note. Robust standard errors in parentheses. $* * * \mathrm{p}<0.01$, $* * \mathrm{p}<0.05$, and $* \mathrm{p}<0.1$

Compilation of data from www.servel.cl and www.inme.cl

Following hypotheses 1 and 2, which evaluate the effect of the percentage of Mapuches on the electoral turnout, the results of the models diverge from conventional wisdom. Although the MAPPEOPLE coefficient is negative in all models, indicating that increases in the percentage of the Mapuche population predict lower levels of electoral turnout, group effects must also be examined. The model indicates that although, in general, increases in the percentage of Mapuche population predict lower levels of turnout, this does not occur when analyzing the group of municipalities that belong to the regions with the highest percentage of the Mapuche population. In this group, the higher the percentage of the Mapuche population, the higher the electoral turnout. Probably, part of the conclusion that support conventional wisdom - that is, that the Mapuche municipalities vote less than the rest - are based on an incomplete statistical model that does not take account of group effects and on a choice to analyze national instead of subnational elections.

Figure 4 compares the model's results for the 2016 subnational elections with those for the 2017 national elections, considering group effects. As can be seen for 2016, increases in the percentage of the Mapuche population are associated with increases in electoral turnout for the group of municipalities that belong to the regions with the highest percentage of the Mapuche population. Simultaneously, for the municipalities that belong to the rest of the country, increases in the percentage of the Mapuche population are associated with decreases in electoral turnout. Simply put, the lines of the expected values cross. In the 2017 national elections, as expected based on the results of the model, Figure 4 shows no statistically significant differences between the groups, and the effect of the percentage of the Mapuche population on the electoral turnout is equal to zero.

Now, it is time to assess hypotheses 3 and 4 concerning the effect of the "political offer" on the electoral turnout. Specifically, it is interesting to know the effect of the political offer of Mapuche candidates. The candidates were classified by coding with " 1 " those who had at least one Mapuche surname and the rest with "0". In total, 25,423 candidates for mayor and councillor in the local elections of 2012 and 2016 were classified from a list of all the candidates of all 345 municipalities of the country. 
With this information, three variables were constructed :

1. The percentage of Mapuche mayoral candidates by the municipality;

2. The percentage of Mapuche candidates for councillor by the municipality; and

3. A dummy variable with a value of 1 when a Mapuche candidate is elected in a municipality, and 0 when a Mapuche candidate does not win.

\section{Figure 4}

Expected Values of Electoral Turnout According to Variations in the Percentage of the Mapuche Population, 2016 and 2017

\section{Local Elections (2016) National Elections (2017)}

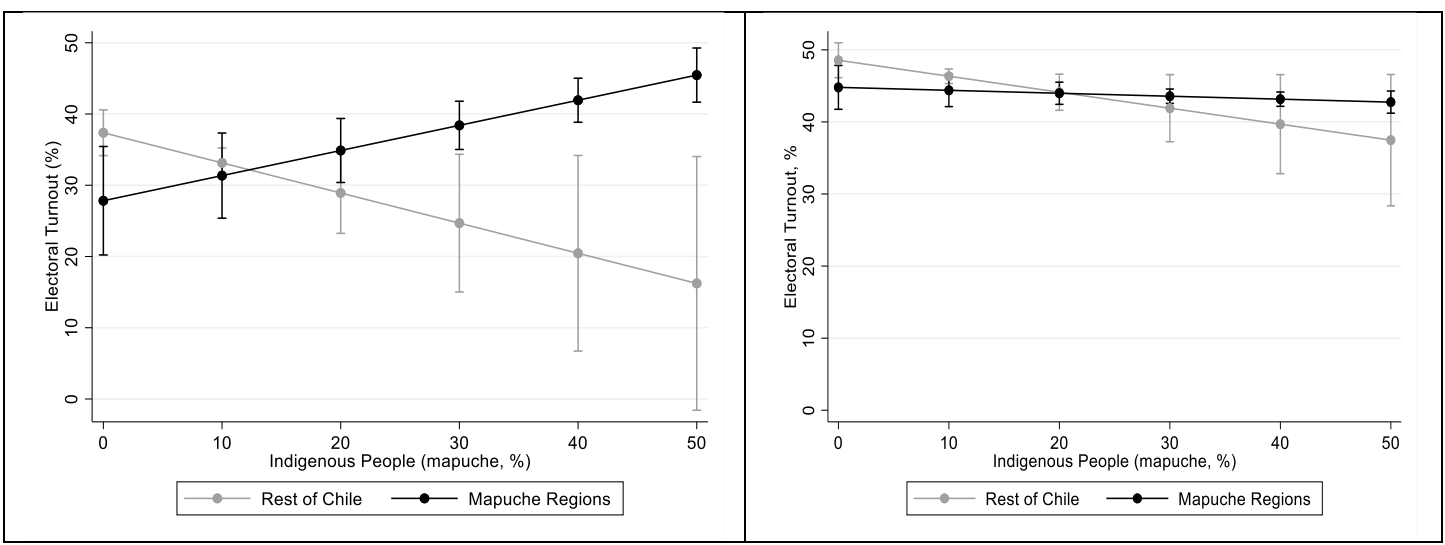

Note. Data from www.servel.cl and www.ine.cl

This last variable was included for the following reasons. The mayor is the most important authority in the municipality. First, in the elections of mayors, which are subnational elections, electoral turnout is higher in those municipalities with the highest concentration of the Mapuche population. Although the percentage of Mapuche mayoral candidates is a good indicator of the "Mapuche political offer," it provides no information on the success of these candidates. There may be municipalities with many Mapuche candidates, but where a non-Mapuche candidate is elected. For this reason, a measure of success was included by identifying those municipalities in which a Mapuche candidate won the seat. This decision may be questionable because the success of a candidate is only known once the people have already turned out to vote. In other words, in a reverse causality, the independent variable (the candidate's success) only happens after the dependent variable (the electoral turnout) has already occurred. Unfortunately, opinion polls in all municipalities to measure the competitiveness of each candidate before the election are lacking, which would eliminate this problem.

That said, the statistical models implemented are based on the following equation:

$$
\begin{aligned}
\text { ETURNOUT }_{i} & =B_{f} \text { GROUPS }++B_{1} \text { MAPPEOPLE }_{i}+B_{f} \text { GROUPS } \\
& * B_{1} \text { MAPPEOPLE }_{i}+B_{2} \text { POVERTY }_{i}+B_{3} \text { DENSITY }_{i} \\
& + \text { SUPPMAPCAND }+\sum_{j=1}^{N} \delta_{j i}++e i
\end{aligned}
$$


Table 5

Determinants of Electoral Turnout (WLS, Ecological Regression), 2012-2016

\begin{tabular}{|c|c|c|c|c|c|c|c|c|}
\hline \multirow[b]{2}{*}{ VARIABLE } & \multicolumn{4}{|c|}{2012} & \multicolumn{4}{|c|}{2016} \\
\hline & 1 & 2 & 3 & 4 & 5 & 6 & 7 & 8 \\
\hline MAPPEOPLE & $\begin{array}{l}-0.263 \\
(0.177)\end{array}$ & $\begin{array}{c}-0.423 * * \\
(0.194)\end{array}$ & $\begin{array}{l}-0.251 \\
(0.181)\end{array}$ & $\begin{array}{c}-0.414 * * \\
(0.196)\end{array}$ & $\begin{array}{c}-0.395 * * * \\
(0.141)\end{array}$ & $\begin{array}{c}-0.385^{* *} \\
(0.159)\end{array}$ & $\begin{array}{c}-0.376 * * * \\
(0.145)\end{array}$ & $\begin{array}{c}-0.350 * * \\
(0.163)\end{array}$ \\
\hline GROUPS ( $0=$ Rest of Chile $1=$ Mapuche regions) & $\begin{array}{c}-9.892 * * * \\
(3.535)\end{array}$ & $\begin{array}{c}-7.386 * * \\
(3.667)\end{array}$ & $\begin{array}{c}-10.10 * * * \\
(3.547)\end{array}$ & $\begin{array}{c}-7.523 * * \\
(3.637)\end{array}$ & $\begin{array}{c}-7.089 * \\
(3.616)\end{array}$ & $\begin{array}{c}-7.257 * \\
(3.822)\end{array}$ & $\begin{array}{c}-7.060 * \\
(3.677)\end{array}$ & $\begin{array}{c}-7.588^{*} \\
(3.985)\end{array}$ \\
\hline GROUPS*MAPPEOPLE & $\begin{array}{c}0.495 * * * \\
(0.190)\end{array}$ & $\begin{array}{c}0.409 * * \\
(0.177)\end{array}$ & $\begin{array}{c}0.501 * * * \\
(0.193)\end{array}$ & $\begin{array}{c}0.413 * * \\
(0.180)\end{array}$ & $\begin{array}{c}0.398 * * \\
(0.176)\end{array}$ & $\begin{array}{c}0.405^{* *} \\
(0.187)\end{array}$ & $\begin{array}{c}0.398 * * \\
(0.184)\end{array}$ & $\begin{array}{c}0.413 * * \\
(0.199)\end{array}$ \\
\hline POVERTY & $\begin{array}{c}0.249 * * \\
(0.104)\end{array}$ & $\begin{array}{c}0.264 * * \\
(0.103)\end{array}$ & $\begin{array}{c}0.249 * * \\
(0.105)\end{array}$ & $\begin{array}{c}0.265^{* *} * \\
(0.103)\end{array}$ & $\begin{array}{c}0.545 * * * \\
(0.0721)\end{array}$ & $\begin{array}{c}0.546^{* * *} * \\
(0.0719)\end{array}$ & $\begin{array}{c}0.537 * * * \\
(0.0718)\end{array}$ & $\begin{array}{c}0.538 * * * \\
(0.0718)\end{array}$ \\
\hline DENSITY & - 0.00 & - 0.00 & - 0.00 & ${ }^{-} 0.00$ & - 0.00 & - 0.00 & -0.00 & - 0.00 \\
\hline & 068 & 067 & 069 & 068 & 060 & 060 & 061 & 061 \\
\hline & $9 * *$ & $7 * *$ & $4 * *$ & $1 * *$ & $4 * *$ & $5^{* *}$ & $0 * *$ & $9 * *$ \\
\hline & $*$ & $*$ & $*$ & $*$ & $*$ & $*$ & $*$ & $*$ \\
\hline SUPPMAPCAND (\% Mapuche mayoral candidates) & $(0.000148)$ & $(0.000143)$ & $\begin{array}{c}(0.000149) \\
0.0137 \\
(0.0552)\end{array}$ & $(0.000143)$ & $(0.000151)$ & $(0.000153)$ & $\begin{array}{c}(0.000150) \\
0.0576 \\
(0.0646)\end{array}$ & $(0.000154)$ \\
\hline SUPPMAPCAND (Mapuche mayors) & $\begin{array}{c}4.172 \\
(4.995)\end{array}$ & $\begin{array}{c}3.461 \\
(4.881)\end{array}$ & & & $\begin{array}{c}8.472 * * \\
(3.544)\end{array}$ & $\begin{array}{c}8.469 * * \\
(3.566)\end{array}$ & & \\
\hline $\begin{array}{l}\text { SUPPMAPCAND (\% Mapuche candidates for } \\
\text { councillor) }\end{array}$ & & $0.301 * *$ & & $0.308 * *$ & & -0.0212 & & -0.0222 \\
\hline Constant & $\begin{array}{c}43.40 * * * \\
(2.048)\end{array}$ & $\begin{array}{c}(0.133) \\
43.20^{* * *} \\
(1.980)\end{array}$ & $\begin{array}{c}43.31 * * * \\
(2.055)\end{array}$ & $\begin{array}{c}(0.135) \\
43.13^{* * * *} \\
(1.980)\end{array}$ & $\begin{array}{c}31.97 * * * \\
(1.878)\end{array}$ & $\begin{array}{c}(0.162) \\
31.98 * * * \\
(1.881)\end{array}$ & $\begin{array}{c}31.85 * * * \\
(1.899)\end{array}$ & $\begin{array}{c}(0.167) \\
31.88 * * * \\
(1.909)\end{array}$ \\
\hline Observations & 345 & 345 & 345 & 345 & 345 & 345 & 345 & 345 \\
\hline R-squared & 0.217 & 0.230 & 0.214 & 0.229 & 0.383 & 0.383 & 0.378 & 0.376 \\
\hline Log Lik & -1224 & -1221 & -1225 & -1222 & -1218 & -1218 & -1220 & -1220 \\
\hline
\end{tabular}

Note. Robust standard errors in parentheses. $* * * \mathrm{p}<0.01, * * \mathrm{p}<0.05$, and $* \mathrm{p}<0.1$

Created with data from www.servel.cl, www.ine.cl 
Unlike the baseline model, two additional control variables are present in this model. These variables are the percentage of poor people by municipality (POVERTY) and the municipality's population density (DENSITY). Additionally, the political offer of Mapuche candidates (SUPPMAPCAND) was included. In the case of the subnational elections of 2012 and 2016, four models were constructed. The first model includes only the dummy variable that distinguishes between municipalities in which a candidate for Mapuche mayor won and the remainder of the municipalities. The second model adds the percentage of Mapuche candidates for mayor. The third model only considers the percentage of Mapuche candidates for mayor. The fourth model only considers the percentage of Mapuche candidates for councilor. The results are given in Table 5.

First, independently of the statistical specification of the models, the coefficients of the variables GROUPS and MAPPEOPLE are as expected. Increases in the percentage of Mapuche population depress the electoral turnout, but in regions with a higher percentage of the Mapuche population, an increase in MAPPEOPLE increases the electoral turnout. In other words, the trend is confirmed regarding the differential effects on the electoral turnout of the percentage of the Mapuche population in those regions with the highest concentration of Mapuche population compared to the rest of the country.

Second, the models show the positive and significant effect of the political offer of Mapuche candidates on electoral turnout, but with some differences when the elections of 2012 and those of 2016 are compared. In 2012, the variable of Mapuche political offer that most affects electoral turnout was the percentage of Mapuche councillors. In 2016, however, the most robust variable to explain electoral turnout was the presence of elected Mapuche mayoral candidates. In these municipalities, electoral turnout stood on average at $45.2 \%$, much higher than the national average of $34.9 \%$. If electoral turnout averages are compared only in the municipalities belonging to the regions with the highest percentage of the Mapuche population, the electoral turnout is $44 \%$ in the municipalities with a Mapuche mayor and $38 \%$ in the remainder of the municipalities. Whether the councillor or mayor are to be elected; the electoral turnout responds positively to the Mapuche political offer.

\section{Concluding Discussion}

This paper discussed two issues. First was the belief that indigenous people vote less than other people. In the analysis by the municipality, precisely the opposite was the case for subnational elections, and the differences between the electoral turnout of indigenous people and the rest of the population are minimal in national elections. In fact, a 2013 survey by the Diego Portales University of Chile (Fuentes 2013) in three municipalities with a high concentration of the Mapuche population conducted months before the presidential election of that year, found that $82 \%$ of Mapuches and non-Mapuches intended to vote. When asked about their past turnout in the 2009 presidential elections (a year in which the vote was still obligatory), $71 \%$ of non-Mapuches and $68 \%$ of Mapuches (a difference that was not statistically significant) indicated that they voted in those elections.

Consequently, the results of this study at the level of national elections are congruent with the findings of this opinion survey conducted, as noted, in three municipalities with a high concentration of Mapuche population. In the case of subnational elections, a survey by the Center for Public Studies before the 2016 municipal elections showed no statistically significant differences between Mapuches and non-Mapuches on their intention to vote, with both groups close to 55\%. However, that the Mapuche population in this survey was 
measured at the national level, without overrepresenting those municipalities with the highest concentration of Mapuche population. Therefore, the conclusions of this survey are limited.

Why do Mapuches in municipalities with the largest Mapuche populations turn out in greater numbers in subnational elections than in national elections? A possible answer concerns the subjective relevance of these elections. Although national elections to choose the president of the Republic attract greater public interest and, in general, higher turnout levels are recorded at the national level, the candidates speak to the average voter and not necessarily to ethnic minorities. The alternative for these minorities is to pursue a descriptive representation at the subnational level by electing candidates of the same ethnic group, whom they trust once elected to promote an agenda focused on the needs of that minority. Thus, the enormous differences in electoral turnout for subnational elections respond to a simple fact: ethnic minorities attribute more relevance to elections that impact their daily lives and less relevance to elections that aim to guide the destiny of the country. In other words, for ethnic minorities, power is exercised more in the municipality by choosing a mayor than at the national level by choosing a president.

If the assumption if that descriptive representation can transmute into a substantive representation at the local level in the case of ethnic minorities, then the mechanism that facilitates this transition must be identified. According to the evidence discussed in this article, variations in the political offer are a possible mechanism. Following empowerment theory, ethnic minority voters will prefer candidates who represent the minority to which they belong. According to the survey conducted by Diego Portales University in 2013 in three municipalities with a sizeable Mapuche population, almost 20\% of the Mapuches indicated that they would always vote for a Mapuche candidate whatever the candidate's ideology, a percentage that drops to less to than $6 \%$ in the non-Mapuche population. In part, this is what Contreras and Morales (2017) define as an "ethnic solidarity" vote, a phenomenon that they also demonstrate at the polling station level. The authors do not determine, however, whether the Mapuche political offer impacts levels of electoral turnout. According to the results of this current study, this impact is evident. The municipalities with the greatest Mapuche political offer show higher levels of electoral turnout. This is particularly evident for sub-national elections. The presence of Mapuche candidates for councilor was a robust predictor of the electoral turnout in 2012. For the 2016 subnational elections, the electoral success of a Mapuche mayoral candidate also significantly increase electoral turnout.

A complementary interpretation suggests that the differences in the electoral turnout of the indigenous people in national and subnational elections are also associated with the type of bond these citizens establish with their municipality. Given that the Chilean state does not even recognize indigenous peoples constitutionally and conflict persists over the return of Mapuche ancestral territory, the municipality is the only state institution linking the Mapuche citizen with the political system. As already noted, those municipalities with the largest Mapuche populations live in conditions of poverty and exclusion. It is these municipalities that channel the most immediate demands of the indigenous people. Presumably, political leaders belonging to the traditional parties exploit this context by reproducing a client relationship with their electors that enables them to mobilize them on election day.

This discussion suggests that any study of the electoral turnout of indigenous people should consider the two dimensions discussed here: subnational elections and the 
characteristics of the political offer. Although it is relevant to know the characteristics of party systems, the presence or absence of ethnic parties, the levels of ethnic fragmentation, and the emergence of ethnic leadership, it also seems appropriate to include factors that explain the electoral turnout, and not only the electoral preferences of indigenous people. In summary, the following were the study's conclusions:

a) Mapuches vote more in local elections than in national elections.

b) Mapuches vote more in local elections when the mayoral candidates are also Mapuche.

c) In line with other research (Bird et al., 2016; Contreras \& Morales, 2017; Van der Zwan et al., 2020), this study provides more evidence on ethnic affinity voting. Indigenous people not only vote more for candidates who are like them in ethnic terms but turn out in greater numbers to vote when the supply of candidates is also ethnically alike.

d) Finally, this study shows empirically the importance of descriptive representation in historically marginalized ethnic groups, following (in part) the theoretical discussion elaborated by Pitkin (1967), Mansbridge (1999) and Barreto et al. (2005), among others.

How relevant is this study beyond Chile? At a comparative level, this study advances in a similar direction to that of Herrick et al. (2020), who analyze the indigenous vote in the United States. One of the most important questions about ethnic voting has precisely concerned levels of electoral turnout. That is, if indigenous people feel integrated in the political system or if they choose to marginalize themselves from it. My findings support the thesis that indigenous people feel more integrated in the local political system than the national one. I take issue with literature that, when analyzing national elections by preference, concludes that indigenous people are structurally marginalized from political systems (Madrid, 2005; Oskooii, 2018).

Moreover, the study is suggestive, following Saglie et al. (2020), of the possible emergence and consolidation of an ethnic cleavage. As I pointed out in the introduction, electoral turnout in municipalities with a high concentration of Mapuche population is greater than the rest of the municipalities, at least in local elections. This statistically robust territorial pattern could reflect the emergence of an ethnic cleavage for two reasons. First, because electoral turnout increases substantially when there is a Mapuche political offer. Second, because - according to Contreras and Morales (2017) - Mapuche voters vote for Mapuche candidates regardless of whether the coalition those candidates represent is center-left or center-right. These two characteristics could, then, reveal the presence of an ethnic cleavage, although in the Chilean case this is only apparent when local elections are analyzed.

Finally, this study suggests the need for a deeper examination of the political behavior of indigenous people in subnational elections. As I showed in the introduction, generally the literature on ethnic voting is based mainly on national elections. At the national level, the particularities of the political behavior of indigenous people are probably not observable, yet they do emerge in subnational analysis.

\section{References}

Akpan, L. (2018). The Political undertone in the development of nomadic education in Africa: Lessons from Nigeria. American Journal of Qualitative Research, 2(1), 121. https://doi.org/10.29333/ajqr/5791 
Almond, G., \& Verba, S. (1963). The civic culture: Attitudes and democracy in five nations. An analytical study. Little, Brown and Company.

Ambrecht, B., \& Pachon, H. (1974). Ethnic political mobilization in a Mexican American community an exploratory study of East Los Angeles 1965-1972. The Western Political Quarterly, 27(3), 500-519. https://doi.org/10.1177/106591297402700309

Anderson, C., \& Beramendi, P. (2008). Democracy, inequality and representation: A comparative perspective. Oxford University Press.

Arthur, P. (2009). Ethnicity and electoral politics in Ghana's Fourth Republic. Africa Today, 56(2), 45-73. https://www.jstor.org/stable/10.2979/aft.2009.56.2.44

Barreto, M. A., Villarreal, M., \& Woods, N. D. (2005). Metropolitan Latino political behavior: Voter turnout and candidate preference in Los Angeles. Journal of Urban Affairs, 27(1), 71-91. https://doi.org/10.1111/j.0735-2166.2005.00225.x

Basedau, M., \& Stroh, A. (2012). How ethnic are African parties really? Evidence from four Francophone countries. International Political Science Review, 33(1), 5-24. https://doi.org/10.1177/0192512110391770

Beck, S., \& Mijeski, K. (2006). The indigenous vote in Ecuador's 2002 presidential election. Latin American and Caribbean Ethnic Studies, 1(2), 165-84. https://doi.org/10.1080/17442220600859338

Bird, K., Jackson, S. D., McGregor, R. M., Moore, A. A., \& Stephenson, L. B. (2016). Sex (and ethnicity) in the city: Affinity voting in the 2014 Toronto mayoral election. Canadian Journal of Political Science, 49(2), 359-383. https://doi.org/10.1017/ S0008423916000536f

Blais, A. (2006). What affects voter turnout? Annual Review of Political Science, 9(1), 111125. https://doi.org/10.1146/annurev.polisci.9.070204.105121

Blais, A., Gidengil, E., Nevitte, N., \& Nadeau, R. (2004). Where does turnout decline from? European Journal of Political Research, 43(2), 221-236. https://doi.org/10.1111/ j.1475-6765.2004.00152.x

Bobo, L., \& Gilliam, F. D. (1990). Race, sociopolitical participation, and Black empowerment. American Political Science Review, 84(2), 377-93. https://www.jstor.org/stable/1963525

Bueno, N., \& Dunning, T. (2017). Race, resources, and representation: Evidence from Brazilian politicians. World Politics, 69(2), 327-365. https://www.muse.jhu.edu/ article/652339

Campbell, D. E. (2006). Why we vote: How schools and communities shape our civic life. Princeton University Press.

Carlson, J. (1984). The impact of ethnicity on candidate image. Polity, 16(4), 667-672. https://doi.org/10.2307/3234635

Chandra, K. (2004). Why ethnic parties succeed: Patronage and ethnic headcounts in India. Cambridge University Press.

Chandra, K. (2005). Ethnic parties and democratic stability. Perspectives on Politics, 3(2), 235-252. https://www.jstor.org/stable/3688028

Contreras, G., \& Morales, M. (2017). Ethnic solidarity and the vote: Mapuche candidates and voters in Chile. Journal of Ethnic and Migration Studies, 44(11), 25-41. https://doi.org/10.1080/1369183X.2017.1371582 
Contreras, G., Joignant, A., \& Morales, M. (2016). The return of censitary suffrage? The effects of automatic voter registration and voluntary voting in Chile. Democratization, 23(3), 520-544. https://doi.org/10.1080/13510347.2014.986720

Corvalán, A., \& Cox, P. (2013). Class-biased electoral participation: The youth vote in Chile. Latin American Politics and Society, 55(3), 47-68. https://doi.org/10.1111/j.15482456.2013.00202.x

Dabin, S., Daoust, J., \& Papillon, M. (2018). Indigenous peoples and affinity voting in Canada. Canadian Journal of Political Science, 52(1), 39-53. https://doi.org/10.1017/S0008423918000574

Dalton, R. J. (2017). The participation gap: Social status and political inequality. Oxford University Press.

Dancygier, R. (2017). Dilemmas of inclusion. Muslims in European politics. Princeton University Press.

Dunning, T., \& Harrison, L. (2010). Cross-cutting cleavages and ethnic voting: An experimental study of cousinage in Mali. American Political Science Review, 104(1), 21-39. https://www.jstor.org/stable/27798538

Durston, J. (2007). Poder local y movimiento étnico en Villarrica, Chile [Local power and ethnic movement in Villarrica, Chile]. In W. Assies \& H. Gundermann (Eds.), Movimientos indígenas y gobiernos locales en Latinoamérica. Copublicación de El Colegio de Michoacán, IWGIA y la U. Católica del Norte.

Featherman, S. (1983). Ethnicity \& ethnic candidates: Vote advantages in local elections. Polity, 15(3), 397-415. https://www.jstor.org/stable/3234669

Fisher, S., Heath, A., Sanders, D., \& Sobolewska, M. (2015). Candidate ethnicity and vote choice in Britain. British Journal of Political Science, 45(4), 883-905. https://doi.org/10.1017/S0007123413000562

Flesken, A., \& Hartl, J. (2020). Ethnicity, inequality, and perceived electoral fairness. Social Science Research, 85, 1-13. https://doi.org/10.1016/j.ssresearch.2019. 102363

Förster, A. (2018). Ethnic heterogeneity and electoral turnout: Evidence from linking neighbourhood data with individual voter data. Electoral Studies, 53, 57-65. https://doi.org/10.1016/j.electstud.2018.03.002

Fowler, J., \& Dawes, C. (2008). Two genes predict voter turnout. The Journal of Politics, 70(3), 579-594.

Fraga, B. (2016). Candidates or districts? Reevaluating the role of race in voter turnout. American Journal of Political Science, 60(1), 97-122. https://doi.org/10.1111/ ajps. 12172

Fuentes, C. (2013). Representation and ethnic minorities: Right-wing party strategies in Mapuche areas. FONDECYT Project No. 1120206, Santiago, Chile.

Fuentes, C., De Cea, M., \& Teitelboim, B. (2019). Presidenciales chilenas 2017. Por quién y cuánto votan los indígenas [Chilean presidential elections 2017. For whom and how much do indigenous people vote]. Estudios Políticos, 55, 14-36.

Gallego, A. (2010). Understanding unequal turnout: Education and voting in comparative perspective. Electoral Studies, 29(2), 239-248. https://doi.org/10.1016/j.electstud. 2009.11.002

Gamboa, R., \& Morales, M. (2016). Chile's 2015 electoral reform. Changing the rules of the game. Latin American Politics \& Society, 58(4), 126-144. https://doi.org/10.1111/laps.12005 
Gatrell, J. D., \& Bierly, G. D. (2002). Weather and voter turnout: Kentucky primary and general elections, 1990-2000. Southeastern Geographer, 42(1), 114-134. https://www.jstor.org/stable/44371132

Gelman, A., Park, D. K., Ansolabehere, S., Price, P. N., \& Minnite, L. C. (2001). Models, assumptions and model checking in ecological regressions. Journal of the Royal Statistical Society: Series A (Statistics in Society), 164(1), 101-118. https://doi.org/10.1111/1467-985X.00190

Geys, B. (2006). Explaining voter turnout: A review of aggregate-level research. Electoral Studies, 25(4), 637-663. https://doi.org/10.1016/j.electstud.2005.09.002

Gundermann, H. (2007). Municipios y pueblos indígenas en Chile [Municipalities and indigenous peoples in Chile]. In W. Assies \& H. Gundermann (Eds.), Movimientos indígenas y gobiernos locales en Latinoamérica (pp. 161-198). Copublicación de El Colegio de Michoacán, IWGIA y la U. Católica del Norte.

Hahn, H., \& Almy, T. (1971). Ethnic politics and racial issues: Voting in Los Angeles. The Western Political Quarterly, 24(4), 719-730. https://doi.org/10.1177/ 106591297102400408

Herrick, R., Davis, J., \& Pryor, B. (2020). Are indigenous Americans unique in their voting in U.S. national elections? Politics, Groups, and Identities. https://doi.org/10.1080/21565503.2020.1782952

Hiskey, J., \& Goodman, G. (2011). The participation paradox of indigenous autonomy in Mexico. Latin American Politics and Society, 53(2), 61-86. https://doi.org/ 10.1111/j.1548-2456.2011.00117.x

Hofferth, S., \& Iceland, J. (1998). Social capital in rural and urban communities. Rural Sociology, 63(4), 574-598. https://doi.org/10.1111/j.1549-0831.1998.tb00693.x

Htun, M. (2016). Inclusion without representation in Latin America. Gender quotas and ethnic reservations. Cambridge University Press.

Jackman, R. (1987). Political institutions and voter turnout in industrial democracies. American Political Science Review, 81(2), 405-424. https://www.jstor.org/ stable/1961959

James, K. (2019). The Stagnation, fall and rise of Singapore's Political Opposition, 19962013. American Journal of Qualitative Research, 3(1), 3756. https://doi.org/10.29333/ajqr/5810

Johnson, M. (2020). Electoral discrimination: The relationship between skin color and vote buying in Latin America. World Politics, 72(1), 80-120. https://doi.org/10.1017/S0043887119000145

Kamin, L. J. (1958). Ethnic and party affiliation of candidates as determinants of voting. Canadian Journal of Psychology, 12(4), 205-213. https://www.jstor.org/stable/ 3231812

Kernecker, T., \& Wagner, M. (2019). Niche parties in Latin America. Journal of Elections, Public Opinion and Parties, 29(1), 102-124. https://doi.org/10.1080/ 17457289.2018.1464014

Knoke, D., \& Felson, R. B. (1984). Ethnic stratification and political cleavage in the United States, 1952-68. American Journal of Sociology, 80(3), 630-642. https://www.jstor.org/stable/2777251 
Korovkin, T. (2006). Indigenous movements in the Central Andes. Latin American and Caribbean Ethnic Studies, 1(2), 143-163. https://doi.org/10.1080/ 17442220600859221

Lehoucq, F., \& Wall, D. L. (2004). Explaining voter turnout rates in new democracies: Guatemala. Electoral Studies, 23(3), 485-500. https://doi.org/10.1016/S02613794(03)00055-6

Lijphart, A. (1997). Unequal participation: Democracy's unresolved dilemma. Presidential Address. American Political Science Review, 91(1), 1-14. https://doi.org/10.2307/2952255

Lublin, D. (2017a). Electoral systems, ethnic diversity and party systems in developing democracies. Electoral Studies, 476, 84-93. https://doi.org/10.1016/j.electstud. 2016.11.012

Lublin, D. (2017b). Electoral systems, ethnic heterogeneity and party system fragmentation. British Journal of Political Science, 47(2), 373-389. https://doi.org/10.1017/S0007123415000137

Mackerras, M., \& McAllister, I. (1999). Compulsory voting, party stability and electoral advantage in Australia. Electoral Studies, 18(2), 217-233. https://doi.org/10.1016/ S0261-3794(98)00047-X

Madrid, R. (2005). Indigenous voters and party system fragmentation in Latin America. Electoral Studies, 24(4), 689-707. https://doi.org/10.1016/j.electstud.2005.02.005

Madrid, R. (2011). Ethnic proximity and ethnic voting in Peru. Journal of Latin American Studies, 43(2), 267-297. https://doi.org/10.1017/S0022216X11000034

Madrid, R. (2018). The emergence of ethno-populism in Latin America. In C. De la Torre, (Ed.), Routledge handbook of global populism. Routledge.

Mainwaring, S., \& Scully, T. (1995). Building democratic institutions. Party systems in Latin America. Stanford University Press.

Mansbridge, J. (1999). Should Blacks represent Blacks and women represent women? A contingent "yes." The Journal of Politics, 61(3), 628-657. https://www.jstor.org/ stable/2647821

Manzano, S., \& Sánchez, G. R. (2010). Take one for the team? Limits of shared ethnicity and candidate preferences. Political Research Quarterly, 63(3), 568-580. https://doi.org/ 10.1177/1065912909333130

Martinez i Coma, F., \& Nai, A. (2017). Ethnic diversity decreases turnout. Comparative evidence from over 650 elections around the world. Electoral Studies, 49, 75-95. https://doi.org/10.1016/j.electstud.2017.07.002

Martinez i Coma, F., \& Werner, A. (2019). Compulsory voting and ethnic diversity increase invalid voting while corruption does not: An analysis of 417 parliamentary elections in 73 countries. Democratization, 26(2), 288-308. https://doi.org/10.1080/ 13510347.2018.1524879

McConnaughy, C., White, I., Leal, D., \& Casellas, J. (2011). A Latino on the ballot: Explaining coethnic voting among Latinos and the response of White Americans. The Journal of Politics, 72(4), 1199-1211.

Ordeshook, P. C., \& Shvetsova, O. V. (1994). Ethnic heterogeneity, district magnitude and the number of parties. American Journal of Political Science, 38(1), 100-123. https://www.jstor.org/stable/2111337

Oskooii, K. (2018). Perceived discrimination and political behavior. British Journal of Political Science, 50(3), 867-892. https://doi.org/10.1017/S0007123418000133 
Painemal, N. (2011). Apellidos mapuche vinculados a títulos de merced [Mapuche surnames linked to deeds of mercy]. Corporación Nacional de Desarrollo Indígena de Chile (CONADI).

Payne, J. M., Zovatto, D., Carrillo, F., \& Allamand, A. (2003). La política importa: Democracia y desarrollo en América Latina [Politics matters: Democracy and development in Latin America]. BID/Instituto Internacional para la Democracia y la Asistencia Electoral.

Persson, M., Sundell, A., \& Öhrvall, R. (2014). Does election day weather affect voter turnout? Evidence from Swedish elections. Electoral Studies, 33, 335-342. https://doi.org/10.1016/j.electstud.2013.07.021

Pettigrew, S. (2020). The downstream consequences of long waits: How lines at the precinct depress future turnout. Electoral Studies, https://doi.org/10.1016/j.electstud.2020.102188

Piliavin, J. (1987). Age, race, and sex similarity to candidates and voting preference. The University of Wisconsin.

Pitkin, H. (1967). The concept of representation. University of California Press.

Powell, G. (1986). American voter turnout in comparative perspective. American Political Science Review, 80(1), 17-43. https://www.jstor.org/stable/1957082

Remmer, K. (2010). Political scale and electoral turnout: Evidence From the less industrialized world. Comparative Political Studies, 43(3), 275-303. https://doi.org/10.1177/0010414009352638

Rice, R., \& Van Cott, D. L. (2006). The emergence and performance of indigenous peoples' parties in South America. A subnational statistical analysis. Comparative Politics, 39(6), 709-732. https://doi.org/10.1177/0010414005285036

Rosenthal, M., Zubida, H., \& Nachmias, D. (2017). Voting locally abstaining nationally: Descriptive representation, substantive representation and minority voters' turnout. Ethnic and Racial Studies, 41(9), 1632-1650. https://doi.org/10.1080/01419870.2017.1295161

Saglie, J., Mörkenstam, U., \& Bergh, J. (2020). Political cleavages in indigenous representation: The case of the Norwegian and Swedish Sámediggis. Nationalism and Ethnic Politics, 26(2), 105-125. https://doi.org/10.1080/13537113.2020.1754555

Stockemer, D., \& Scruggs, L. (2012). Income inequality, development and electoral turnout - New evidence on a burgeoning debate. Electoral Studies, 31(4), 776-773. https://doi.org/10.1016/j.electstud.2012.06.006

Toro, S., \& Jaramillo, N. (2014). Despejando mitos sobre el voto indígena en Chile. Preferencias ideológicas y adhesión étnica en el electorado Mapuche [Dispelling myths about the indigenous vote in Chile. Ideological preferences and ethnic adherence in the Mapuche electorate]. Revista de Ciencia Política, 34(3), 583-604. https://doi.org/10.4067/S0718-090X2014000300004

Tricot, V., \& Bidegain, G. (2020). En busca de la representación política: El partido mapuche Wallmapuwen en Chile [In search of political representation: The Mapuche Wallmapuwen party in Chile]. Estudios Sociológicos, 38(113), 375-407.

Valenzuela, M., Toro, S., \& Rojo, F. (2017). Equal in poverty, unequal in wealth: Ethnic stratification in Chile, the Mapuche case. Bulletin of Latin American Research, 36(4), 526-541. https://doi.org/10.1111/blar.12558 
Van Cott, D. L. (2005). From movements to parties in Latin America. The evolution of ethnic politics. Cambridge University Press.

Van der Zwan, R., Tolsma, J., \& Lubbers, M. (2020). Under what conditions do ethnic minority candidates attract the ethnic minority vote? How neighbourhood and candidate characteristics affected ethnic Affinity voting in the Dutch 2017 parliamentary elections. Political Geography, 77, 102098. https://doi.org/ 10.1016/j.polgeo.2019.102098

Wolfinger, R. E. (1965). The development and persistence of ethnic voting. The American Political Science Review, 59(4), 896-908. https://www.jstor.org/stable/1953212

Yashar, D. (2005). Contesting citizenship in Latin America: The rise of indigenous movements and the postliberal challenge. Cambridge University Press.

\section{Notes on Contributor}

Mauricio Morales Quiroga. PhD in Political Science. Full Professor, School of Political Science and Public Administration, Faculty of Social and Juridical Sciences, Universidad de Talca, Campus Santiago, Chile. His work has published by Democratization, Journal of Ethnic and Migration Studies, Journal of Women, Policits\&Policy, European Review of Latin American and Caribbean Studies, Latin American Politics\&Society, Latin American Research Review, Política y Gobierno, Revista de Ciencia Politica. This research is sponsored by by Fondecyt Project number 1180009 of Conicyt. ORCID: http://orcid.org/0000-0001-6010-9604. 